\title{
TEN YEARS STORAGE OF THE VACCINATION STRAIN OF TRICHOPHYTON VERRUCOSUM IN THE LYOPHILIZED STATE
}

\section{A. RYBNIKÁR̆}

Bioveta, n. p., 68323 Ivanovice na Hané

Received December 16, 1988

Abstract

R y b n i káf, A.: Ten Years Storage of the Vaccination Strain of Trichophyton verrucosum in the Lyophilized State. Acta vet. Brno, 58, 1989 :363-367.

The vaccination strain of Trichophyton verrucosum CCM E-650, which is the basic active ingredient of the Czechoslovak lyophilized living vaccine against bovine trichophytosis showed the same growth capacity after 10-year storage of the vaccine in a refrigerator as were exhibited by freshly-prepared lyophilized culture. The proportions of colony-forming units assessed in 21 batches of the vaccine by the plate dilution method after 10-year storage ranged from 26.2 to $89.7 \%$, compared with the values obtained immediately after lyophilization. The potency of the vaccine stored for 10 years was found to equal that of a freshly-prepared batch when tested by challenge bioassay on calves.

Vaccine against bovine trichophytosis, viability of the culture, growth rate, potency

The method of immunoprophylaxis and immunotherapy of bovine trichophytosis using specific vaccines as was introduced into veterinary practice in the early 70's by Soviet investigators ( $\mathrm{S}$ a r $\mathrm{k}$ i s o v et al. 1972) has proved useful also in large herds of cattle in Czechoslovakia. Besides the Soviet vaccine, LFT-130, which was used in our country for immunization of cattle against bovine trichophytosis in 1976-1980, a lyophilized vaccine of Czechoslovak origin has been used in our herds on an increasingly larger extent since 1974. The basic active ingredient of our vaccine is a lyophilized living culture of Trichophyton verrucosum. During storage of the vaccine a decrease in the number of viable $T$. verrucosum elements generally occurs. A previous investigation ( $R$ y $b$ $\mathrm{n}$ i k a $\mathbf{~}$ 1981) showed that one-year maintenance of the lyophilized culture in a refrigerator produced only little decrease of its viability and no negative effects on its potency. Accordingly, its expiry date was given as one year after production. The object of the present study was to assess the viability, growth and immunization capacity of the vaccination strain after its storage in the lyophilized state for 10 years.

\section{Materials and Methods}

In 21 batches of the commercial lyophilized vaccine against bovine trichophytosis (manufactured by Bioveta n. p., Ivanovice na Hané, Czechoslovakia) the number of colony-forming units (CFU) of the vaccination strain Trichophyton verrucosum Bodin 1902 CCM E-650 was assessed immediately after lyophilization by the plate dilution method. The procedure was the same as described in our previous report ( $R$ y b $n$ i k a $y$ 1981). From each batch of the vaccine three samples were taken and maintained in the lyophilized state at 2 to $8^{\circ} \mathrm{C}$ for ten years. Afterwads the number of CFU of $T$. verrucosum was assessed by seeding the logarithmically diluted vaccine.

The growth rate of vaccination strain of T.'verrucosum grown on Sabouraud's agar from samples of the vaccine maintained for 10 years was assessed by measuring the diameters of 20 colonies. The resultant values were compared with the results of growth in control samples of the freshly-prepared vaccine.

The vaccine maintained in the lyophilized state for 10 years was tested for potency in a challenge bioassay on one-month-old calves divided into three groups of six animals.

/1/ Group 1: animals were vaccinated twice i. $\mathrm{m}$. with the vaccine maintained in a refrigerator for 10 years 
12/ Group 2: animals were vaccinated twice i. $\mathrm{m}$. with the freshly-prepared vaccine. The interval between vaccination and revaccination in the two groups was $14 \mathrm{~d}$.

13/ Group 3:animals were non-vaccinated controls.

One month after revaccination the immunized calves, and the controls, were challenged epicutaneously with a virulent $T$. verrucosum strain. The suspension of the challenge culture was inoculated at the rate of 5 milion CFU per animal into a $10 \times 10 \mathrm{~cm}$ area of the clipped and gently scarified skin. The animals were observed for clinical mycotic skin changes at the site of appplication of the challenge culture for 31 days after challenge.At the end of the experiment samples of the skin alterations (scales and hairs) were taken for mycological examination. The challenge culture was examined for the presence of CFU by culture on Sabouraud's agar with chloramphenicole and cyclohemixide at $28^{\circ} \mathrm{C}$.

\section{Results}

The numbers of surviving CFU of the vaccination strain of $T$. verrucosum after 10-year storage of vaccine in a refrigerator are shown in Table 1 . The proportion of CFU after the storage, compared with the values recorded immediately after lyophilization, ranged from 26.2 to $89.7 \%$.

Table 1. Survival of the vaccination strain of Trichophyton verrucosum after 10-year storage of the lyophilized vaccine in a refrigerator

\begin{tabular}{cccc}
\hline $\begin{array}{c}\text { Batch of } \\
\text { vaccine }\end{array}$ & $\begin{array}{c}\text { No CFU in 1 ul of the vaccine } \\
\text { immediately after } \\
\text { lyophilization }\end{array}$ & $\begin{array}{c}\text { after 10-year } \\
\text { storage }\end{array}$ & $\begin{array}{c}\text { \% surviving } \\
\text { CFU }\end{array}$ \\
\hline 080476 & 3.900 & 2.300 & 59,0 \\
140576 & 3.400 & 3.050 & 89,7 \\
190676 & 10.400 & 6.450 & 62,0 \\
521176 & 4.550 & 4.000 & 87,9 \\
541276 & 4.600 & 1.550 & 33,7 \\
130477 & 9.970 & 7.650 & 76,7 \\
190577 & 7.100 & 4.300 & 60,6 \\
260677 & 12.200 & 7.225 & 59,2 \\
300777 & 3.930 & 1.030 & 26,2 \\
340977 & 6.110 & 3.565 & 58,3 \\
031277 & 6.700 & 5.850 & 87,3 \\
041277 & 7.670 & 4.625 & 60,3 \\
090278 & 9.400 & 2.600 & 27,7 \\
100378 & 4.850 & 2.225 & 45,9 \\
170578 & 3.440 & 2.450 & 71,2 \\
210678 & 17.900 & 4.950 & 27,7 \\
220678 & 9.300 & 3.975 & 42,7 \\
250778 & 12.350 & 9.625 & 77,9 \\
280878 & 6.025 & 3.000 & 49,8 \\
320978 & 10.425 & 4.375 & 42,0 \\
331078 & 5.800 & 2.245 & 38,7 \\
\hline
\end{tabular}

Table 2.

Growth rate of the lyophilized vaccination strain of $T$. verrucosum after 10 -year storage in a refifgerator compared with that of freshly-prepared lyophilizates

\begin{tabular}{ccccc}
\hline Age of lyophil- & \multicolumn{4}{c}{ Diameter (in mm) of grown T. verrucosum colonies $(\overline{\mathrm{X}} \pm \mathrm{s} \overline{\mathrm{x}} ; \mathrm{n}-20)$} \\
\cline { 2 - 5 } ized samples & 7 th day & 9th day & 14th day & 19th day \\
\hline 7 days & $4,0 \pm 0,2$ & $10,2 \pm 0,4$ & $23,9 \pm 0,5$ & $38,4 \pm 1,2$ \\
10 years & $4,0 \pm 0,2$ & $10,4 \pm 0,5$ & $23,8 \pm 0,8$ & $38,3 \pm 1,5$ \\
\hline
\end{tabular}


The growth of the vaccination strain showed no difference between the samples of freshly-prepared vaccine and those of the vaccine stored in a refrigerator for 10 years (Table 2).

As can be seen from Table 3, the protective capacity of the vaccination strain of $T$. verrucosum maintained in the lyophilized state for 10 years was quite comparable with that of freshly-prepared lyophilizates. Whether immunized with the freshly-prepared vaccine or with the vaccine stored for 10 years, the calves proved resistant to experimental infection a virulent $T$. verrucosum strain.

Table 3. Potency tests of the lyophilized vaccine against bovine trichophytosis stored for 10 years in a refirigerator by challenge bioassay on calves

\begin{tabular}{|c|c|c|c|c|c|c|}
\hline \multirow[t]{2}{*}{$\begin{array}{l}\text { Experimental } \\
\text { group }\end{array}$} & \multirow[t]{2}{*}{$\begin{array}{l}\text { Calf } \\
\text { No. }\end{array}$} & \multicolumn{5}{|c|}{$\begin{array}{l}\text { Skin mycotic changes at the site of challenge } \\
\text { with T. verrucosum culture, days after challenge }\end{array}$} \\
\hline & & 10th day & 15th day & 20 th day & 26th day & 31 st day \\
\hline $\begin{array}{l}\text { Vaccination } \\
\text { with vaccine } \\
\text { stored for } \\
10 \text { years }\end{array}$ & $\begin{array}{l}298 \\
302 \\
520 \\
521 \\
522 \\
523\end{array}$ & $\begin{array}{l}\overline{-} \\
+ \\
\pm \\
\pm \\
\overline{ \pm} \\
\pm\end{array}$ & $\begin{array}{l}\overline{-} \\
\pm \\
\pm \\
\overline{-} \\
-\end{array}$ & $\begin{array}{l}\bar{t} \\
\overline{-} \\
\overline{-}\end{array}$ & $\begin{array}{l}\overline{ \pm} \\
\underline{-} \\
\overline{-} \\
-\end{array}$ & $\begin{array}{l}\bar{z} \\
\underline{-} \\
\overline{-} \\
\overline{-}\end{array}$ \\
\hline $\begin{array}{l}\text { Vaccination } \\
\text { with } \\
\text { freshly- } \\
\text { prepared } \\
\text { vaccine }\end{array}$ & $\begin{array}{l}384 \\
385 \\
504 \\
505 \\
507 \\
509\end{array}$ & $\begin{array}{l}+ \\
\pm \\
\pm \\
\pm \\
\pm \\
-\end{array}$ & $\begin{array}{l} \pm \\
\pm \\
- \\
\pm \\
\pm\end{array}$ & $\begin{array}{l} \pm \\
\pm \\
\pm \\
+\end{array}$ & $\begin{array}{l}\bar{z} \\
\bar{z} \\
\bar{t}\end{array}$ & $\begin{array}{l}\bar{z} \\
\bar{z} \\
\bar{z}\end{array}$ \\
\hline $\begin{array}{l}\text { Non-vacci- } \\
\text { nated } \\
\text { contols }\end{array}$ & $\begin{array}{l}360 \\
391 \\
392 \\
531 \\
549 \\
935\end{array}$ & $\begin{array}{l} \pm \\
\pm \\
\pm \\
-\end{array}$ & $\begin{array}{r}++ \\
+ \\
+ \\
++ \\
+ \\
+\end{array}$ & $\begin{array}{l}+++ \\
++ \\
++ \\
+++ \\
+++ \\
+++\end{array}$ & $\begin{array}{r}+++ \\
++ \\
++ \\
++ \\
+++ \\
+++\end{array}$ & $\begin{array}{r}+++ \\
++ \\
++ \\
++ \\
+++ \\
+++\end{array}$ \\
\hline
\end{tabular}

\footnotetext{
- without clinical skin mycotic changes

$\pm \quad$ minute skin mycotic changes

+ solitary mycotic changes

++ more than 10 mycotic foci tending to merge

+++ merging of the foci to confluent crusts
}

Examination at $31 \mathrm{~d}$ after challenge revealed 5 clinically negative calves and 1 animal with minute squamous changes tending to healing in each of the two vaccinated groups. The non-vaccinated challenged controls developed a clinical form of trichophytosis with the incidence of marked confuluent crusts. Mycological examination by culture demonstrated the challenge strain of $T$. verrucosum in skin alterations the controls and yielded invariably negative results in the vaccinated animals. 


\section{Discussion}

The capacity of sporulating filamentous fungi to survive in the lyophilized state for long periods of time is well-known from the relevant literature. B o s $m$ a n s (1974) found good viability of lyophilized pathogenic fungi after 10 years, $R \mathrm{~h}$ o a d e s (1970) after 16-year maintenance of the lyophilizates. E 11 i s and Robers on (1968) reported that lyophilized samples of 447 fungal strains were viable after being stored for as many as 23 years. However, the afore-mentioned investigators provided no information as to the numbers of CFU in the lyophilizates after long-term storage, compared with the initial post-lyophilization values. Quantitative assessment of the survival of lyophilized cultures of dermatophytes was the subject of our previous study in which the viability of the cultures maintained in a refrigerator proved substantially higher than that found after 1-year storage at room temperature ( $\mathrm{K}$ y b n i ká $\mathrm{Y}$ et al. 1987).

Similar results were also obtained with the Soviet vaccination strain of $T$. verrucosum: storage of vaccine LTF-130 at room temperature for 3 months produced a decrease in the number of CFU and, in consequence, a decrease in the potency of the vaccine to 30 to $35 \%$ ( $\mathrm{Z} \mathrm{h}$ a r k o v 1985).

The Czechoslovak vaccination strain of $T$. verrucosum showed good viability after 3 years of storage in the lyophilized state at refrigerator temperature: about $80 \%$ out of the original post-lyophilization number of fungal elements survived ( $R$ y b n i k á 1981 ). The present study extends the afore-mentioned observations by presenting the results of storage the commercial lyophilized vaccine against bovine trichophytosis for 10 years. Stored for 10 years in the lyophilized state, the Czechoslovak vaccination strain of $T$. verrucosum showed good growth rate equalling that found in freshly-prepared lyophilizates. Also the proportion of $T$. verrucosum CFU surviving in the vaccine after 10-year storage was relatively high: 26.2 . to $89.7 \%$ out of the numbers found immediately after lyophilization. It is noteworthy that 15 out of the 21 batches of the vaccine conformed to the manufacturer's standard as to the number of CFU after as many as 10 years.

A high degree of stability of our vaccine was also confirmed by challenge bioassay on calves. The potency of the vaccine proved good even after 10-year storage; its prophylactic efficiency was entirely comparable with that of a freshly-prepared batch. It should be noted, however, that selected for this experiment was the batch in which the number of CFU after 10-year storage conformed to the standard. No tests of potency were carried out on those batches of the vaccine where CFU numbers after the storage were unsatisfactory.

It can be concluded that under proper storage the lyophilized vaccine against bovine trichophytosis produced by Bioveta n. p., Ivanovice na Hané, maintains the declared technical parameters and good potency frequently for several years after the expiry date. Nevertheless, for application of the vaccine in the field we still recommend to follow the manufacturer's directions as to its 1-year suitability for use so that optimum immunization of the cattle may be achieved. 


\section{Deset let udržování vakciną̌ního kmene Trichophyton verrucosum $\checkmark$ lyofilizovaném stavu}

Vakcinační kmen Trichophyton verrucosum CCM E-650, který tvoří základní účinnou součást Československé vakcíny proti trichofytóze skotu živé lyofilizované, prokázal po deseti letech udržování biopreparátu $\mathbf{v}$ chladničce stejné růstové schopnosti jako čerstvě připravená lyofilizovaná kultura. Počet životaschopných houbových elementů, zjištěný u 21 výrobních šarži vakcíny plotnovou dikuční metodou, se pohyboval po desetiletém uchovávání v rozmezí $26,2-89,7 \%$ v porovnání s hodnotami, získanými ihned po lyofilizaci. Profylaktická účinnost dlouhodobě udržované vakcíny byla testována $\mathrm{v}$ čelenžním biologickém pokusu na telatech. Protekční schopnosti vakcíny, skladované deset let, byly zcela srovnatelné s nově vyrobenou šarži vakcíny.

\section{Десятилетнее содержание вакцины штамма I'richophyton verrucosum - лиофилизированном состолнии}

Штамм вакцины Trichophyton verrucosum CСM Е-650, являющийся основной-активной составной частью чехословацкой живой лиофилизированной трихофитозной вакцины, отличался после десятилетнего содержания биопрепарата в холодильнике ростовыми способностями, присущими свеже подготовленной лиофилизированной культуре. Численность жизнеспособных грибных элементов, выявленная на 21 партии вакцины методом разведения, достигала после десятилетнего хранения пределом 26,2-89,7\% по сравнения со значениями, полученными непосредственно после лиофилизации. Профилактическую действенность длительное время хранимой вакцины проверяли в ходе биологического эксперимента с телятами. Защитные способности десять лет хранимой вакцины вполне сопоставимы с новой выпущенной партией вакцины.

\section{References}

BOSMANS, J.: Ten years lyophilization of pathogenic fungi. Mycopath. Mycol. appl. 3, 1974: $13-23$.

ELLIS, J. J. - ROBERSON, J. A.: Viability of fungus cultures preserved by lyophilization. Mycologia, 60, 1968: 399-405.

RHOADES, H. E.: Effects of 20 years'storage on lyophilized cultures of bacteria, molds, viruses, and yeasts. Amer. J. Vet. Res., 31, 1970: 1867-1870.

RYBNIKÁR, A.: Lyophilization of Trichophyton vernucosum organisms. Acta vet. Brno, 50, 1981: $73-77$.

RYBNIKÁR, A. - SCHMIED, J. - STROSSA, J.: Lyofilizace dermatofytú. Veter. Med. (Praha), 32, 1987: 497-508.

SARKISOV, A. CH. - PETROVIČ, S. V. - NIKIFOROV, L. I. - JABLOČNIK, L. M.: Specificeskaja profilaktika strigušcego lišaja krupnogo rogatogo skota. Bjul. Vses. ord. Lenina inst. eksper. vet., 1972, (12): 9-14.

ZHARKOV, I. I.: Effektivnost immunoprofilaktiki trichofitii. Veterinarija (Moskva), 1985, (11): $22-23$. 